\title{
Expression of C-C Chemokines is Associated with Portal and Periportal Inflammation in the Liver of Patients with Chronic Hepatitis C
}

\author{
Fumihiko Kusano, Yujiro Tanaka, Fumiaki Marumo, and Chifumi Sato \\ Second Department of Internal Medicine (FK, YT, FM), Tokyo Medical and Dental University, and Department of \\ Health Science (CS), Faculty of Medicine, Tokyo Medical and Dental University, Tokyo, Japan
}

\begin{abstract}
SUMMARY: Inflammation of the portal and periportal areas is a common feature of chronic hepatitis C. Antigen-presenting dendritic cells are located in the portal area, and infiltrating T cells are initially exposed to infected hepatocytes in the periportal area. Thus, these areas could be sites of the initial processes of the immune response in chronic hepatitis $\mathrm{C}$. C-C chemokines (dendritic-cell-derived C-C chemokine [DC-CK1] and regulated upon activation, normal T-cell expressed and secreted [RANTES])-attracting $T$ cells may play a role in the portal inflammatory changes. The relationship between the expression of these $\mathrm{C}-\mathrm{C}$ chemokines, which attract $\mathrm{T}$ cells and the infiltration of $\mathrm{T}$ cells into the liver of patients with chronic hepatitis $\mathrm{C}$, was examined by in situ hybridization and reverse transcription-polymerase chain reaction. T-cell activation was examined by immunostaining T-cell subsets. Specific signals were detected for DC-CK1 mRNA in mononuclear cells mainly in the portal area and for RANTES mRNA in the portal area and at sites of piecemeal necrosis in the liver of patients with chronic hepatitis C. Naive T cells were located mainly in the portal area, whereas active T cells were found mainly at sites of piecemeal necrosis in the periportal area. In addition, hepatic DC-CK1- and RANTES-mRNA levels were significantly correlated with serum alanine aminotransferase levels $(p<0.001)$. These results suggest that the local production of DC-CK1 and RANTES participates in immune responses by attracting naive and active T cells to the portal and periportal areas, respectively. (Lab Invest 2000, 80:415-422).
\end{abstract}

P ortal and periportal inflammatory changes such as piecemeal and bridging necrosis are characteristic of chronic nonA and nonB hepatitis (Dienes et al, 1982; Knodell et al, 1981). Portal inflammation and T-cell infiltration are also key features of hepatitis C (Mosnier et al, 1993; Scheuer et al, 1992). We found, by using in situ hybridization of hepatitis $\mathrm{C}$ virus (HCV) RNA, that infiltrating mononuclear cells are initially exposed to infected hepatocytes in the periportal area (Kojima et al, 1996).

Dendritic cells are thought to play an important role in presenting antigen to naive $T$ cells during viral infection (Austyn, 1998; Sprecher and Becker, 1993; Steinman, 1991; Steinman et al, 1993), and these cells are located in the portal area (Kudo et al, 1997; Prickett et al, 1988). The host immunoreaction to HCV-infected cells may therefore be initiated in the portal and periportal areas.

C-C chemokines are a family of low-molecular mass (8-10 kd) with structurally related proteins having no intervening amino acids between their first two cysteine residues; they exhibit various proinflammatory activities, including chemotaxis (Bacon and Schall, 1996; Baggiolini et al, 1994; Hedrick and Zlotnik, 1996;

Received December 10, 1999.

Address reprint requests to: Dr. Y. Tanaka, Second Department of Internal Medicine, Tokyo Medical and Dental University, 1-5-45 Yushima, Bunkyo-ku, Tokyo 113-8519, Japan. Fax: 8135803 0172; E-mail address:ytanaka.med2@med.tmd.ac.jp
Miller and Krangel, 1992; Oppenheim et al, 1991). Dendritic-cell-derived C-C chemokine (DC-CK1) is specifically expressed by dendritic cells in germinal centers but may also be found in T zones (Adema et al, 1997). It has preferential chemotactic activity for naive $\mathrm{T}$ cells. However, another C-C chemokine, referred to as "regulated upon activation, normal T-cell expressed and secreted" (RANTES), attracts active T cells (Schall et al, 1990). We investigated the role of these $\mathrm{C}-\mathrm{C}$ chemokines in portal and periportal inflammation associated with chronic hepatitis $\mathrm{C}$.

\section{Results}

Cellular Localization of DC-CK1 and RANTES in the Liver

In situ hybridization using antisense riboprobes detected specific signals for DC-CK1 mRNA in mononuclear cells mainly from lymphoid follicles of the portal area of the liver of patients with chronic hepatitis $C$ (Fig. 1, a to d). In contrast, signals for RANTES mRNA were detected at sites of piecemeal necrosis as well as in the portal area (Fig. 2, a to c). Nonspecific signals were not detected by sense probes (Figures 1e and $2 \mathrm{~d}$ ), and positive signals were not detected by antisense probes in cells from the normal liver (Figs. 1f and $2 e$ ).

\section{T Cell Subsets in the Liver}

CD45RA-positive cells (naive $T$ cells) were found mainly in the portal area (Fig. 3a), whereas CD45RO- 

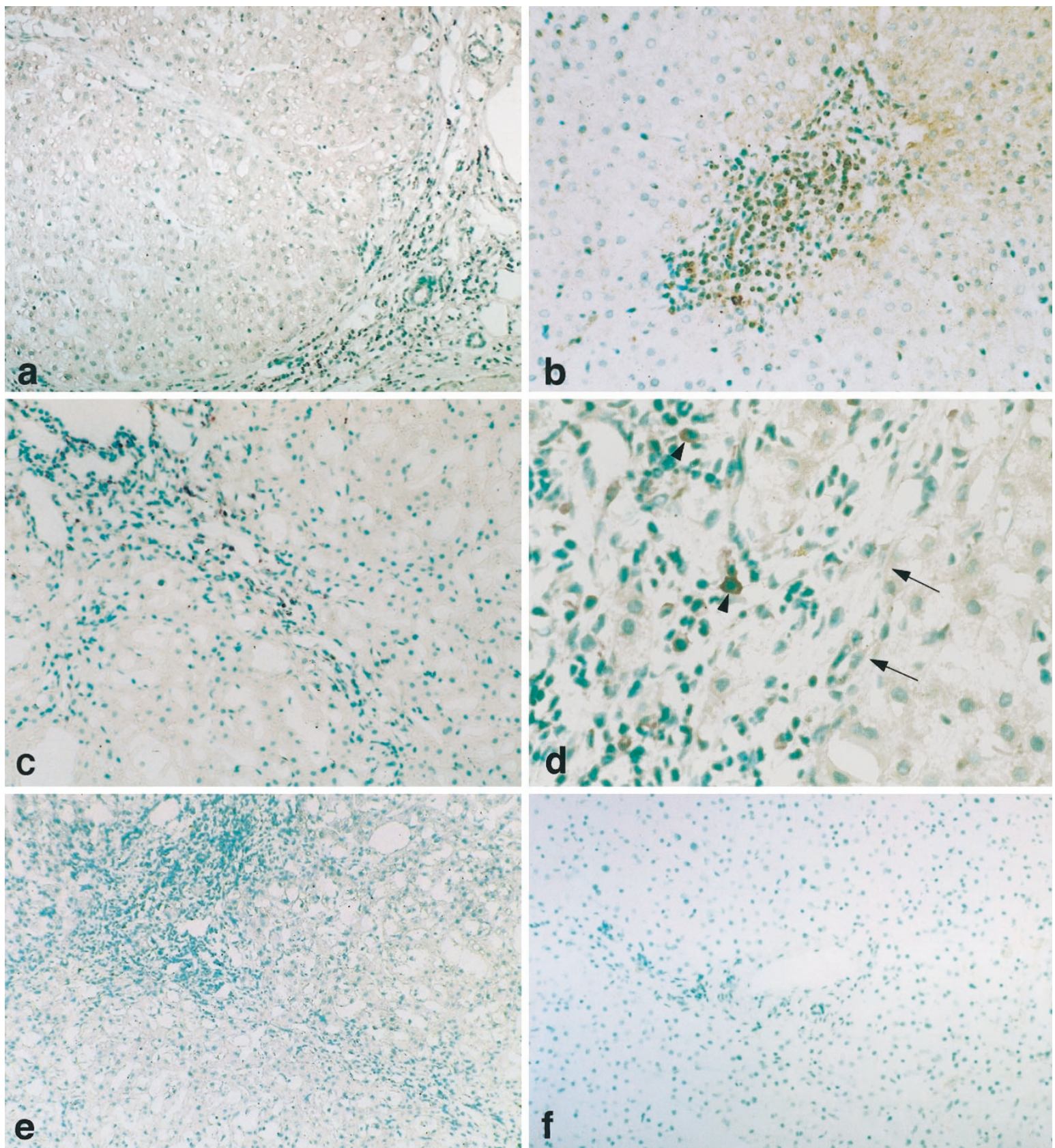

\section{Figure 1.}

In situ hybridization of DC-CK1 mRNA in the liver cells of patients with chronic hepatitis C and in normal controls. In situ hybridization of DC-CK1 mRNA shows positive signals located in the portal area rather than in the lobule (a). Cells are positive in the portal lymphoid follicle $(b)$ and in portal inflammation $(c)$. Positive cells (arrowheads) are apparently distant from the limiting plate (arrows) (d). In situ hybridization with sense probes does not detect non-specific signals (e). Normal liver cells are negative $(f)$. Slides counterstained with methyl green. Magnification: $\times 64(a$ and $e), \times 100(c$ and $f), \times 200(b)$, and $\times 400(d)$.

positive cells (active $T$ cells) were located mainly at sites of piecemeal necrosis in the periportal area (Fig. 3b).

\section{Quantitative Analysis of DC-CK1- and RANTES-mRNA Expression}

We quantified DC-CK1 and RANTES expression using RT-PCR with SYBR Green I in specific melting curves for $\beta$-actin, DC-CK 1 , and RANTES. Curves for $\beta$-actin, DC-CK1, and RANTES constituted straight lines rang- ing from $10^{2}$ to $10^{8}$ copy molecules. The expression of DC-CK1, RANTES, and $\beta$-actin in the liver from 40 patients with chronic hepatitis $C$ is shown in Table 1.

The results showed that both hepatic mRNA levels of DC-CK1 and of RANTES were elevated in liver samples from patients with chronic hepatitis $C$ after correction by comparison with $\beta$-actin-mRNA levels. The expression of DC-CK1 and RANTES was minimal in the controls. In contrast, the correlation was significantly positive between DC-CK $1 / \beta$-actin-mRNA and serum-alanine-aminotransferase (ALT) levels $(r=$ 

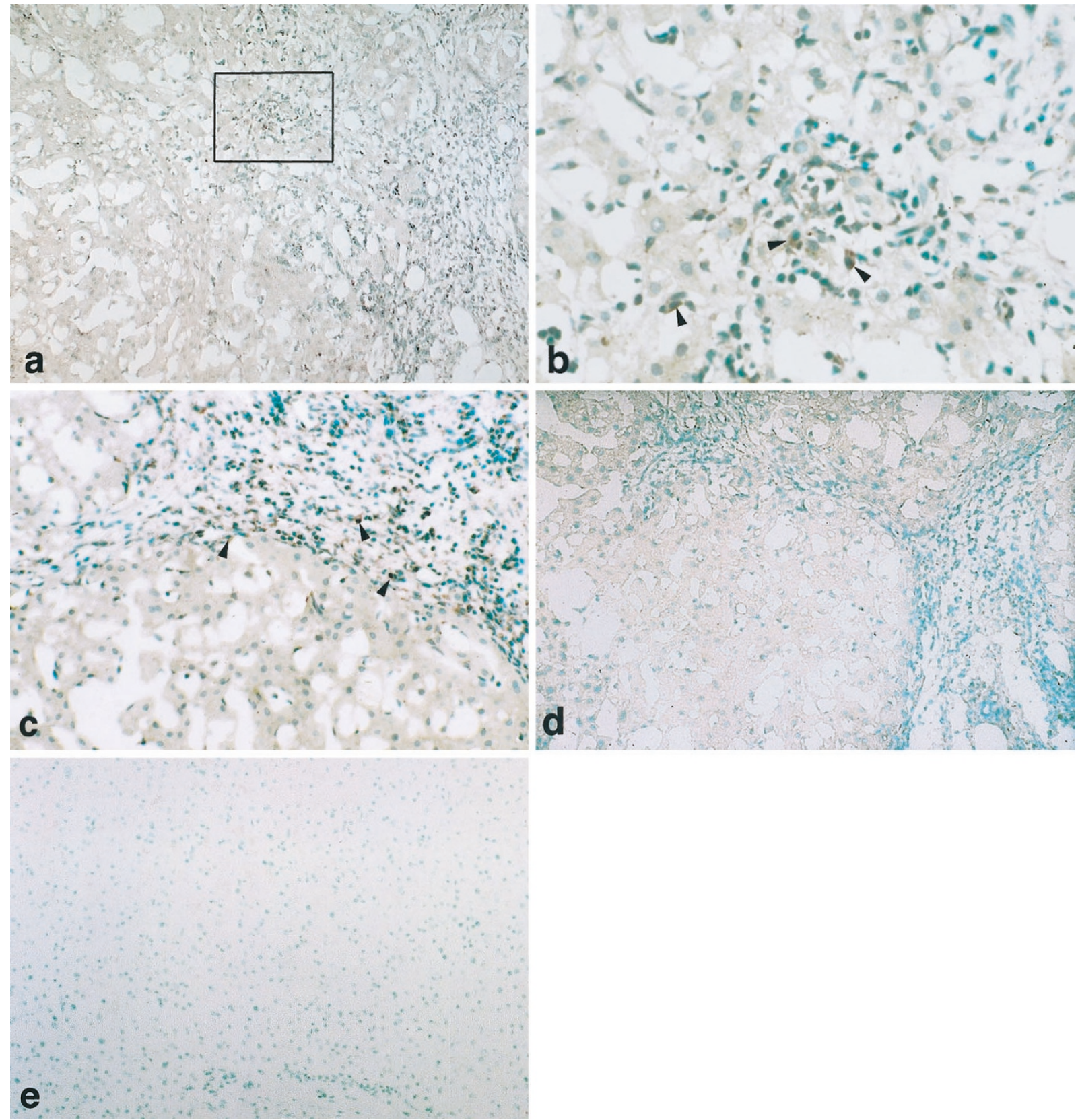

\section{Figure 2.}

In situ hybridization of RANTES mRNA in the liver cells of patients with chronic hepatitis $C$ and in normal controls. In situ hybridization of RANTES mRNA shows positive cells in the portal area and at sites of piecemeal necrosis $(a, b$, and $c$ ). Positive cells (arrowheads) in focal necrosis ( $b$ is higher magnification of area outlined in a) and at sites of piecemeal necrosis $(c)$ at high power magnification. In situ hybridization with sense probes shows no non-specific signals $(d)$. Normal liver cells are negative $(e)$. Slides counterstained with methyl green. Magnification: $\times 64(a, d$, and $e), \times 100(c)$, and $\times 400(b)$.

$0.783, p<0.001)$ and between RANTES $/ \beta$-actinmRNA and serum ALT levels $(r=0.813, p<0.001)$ in liver cells from patients infected with chronic hepatitis C. The correlation between DC-CK $1 / \beta$-actin mRNA and RANTES/ $\beta$-actin mRNA was also significant $(r=$ 0.786, $p<0.001$ ) (Fig. 4).

RANTES/ $\beta$-actin-mRNA levels were significantly elevated in patients with chronic active hepatitis $C$ compared with those of controls (normal versus chronic active hepatitis: $p<0.05$, by Bonferroni/Dunn analysis), whereas DC-CK $1 / \beta$-actin-mRNA levels were not significantly elevated (Fig. 5).

\section{Discussion}

Chemokines are chemotactic cytokines that are classified as either CXC (cysteine-any amino acidcysteine-motif) (or $\alpha$ ) and C-C (cysteine-cysteinemotif) (or $\beta$ ) (Bacon and Schall, 1996; Baggiolini et al, 1994; Hedrick and Zlotnik, 1996; Miller and Krangel, 1992; Oppenheim et al, 1991). The CXC chemokines mainly act on neutrophils, whereas the C-C chemokines target lymphocytes or monocytes (Oppenheim, 1993). Levels of interleukin-8, a CXC chemokine, are elevated in patients with various liver diseases, such 


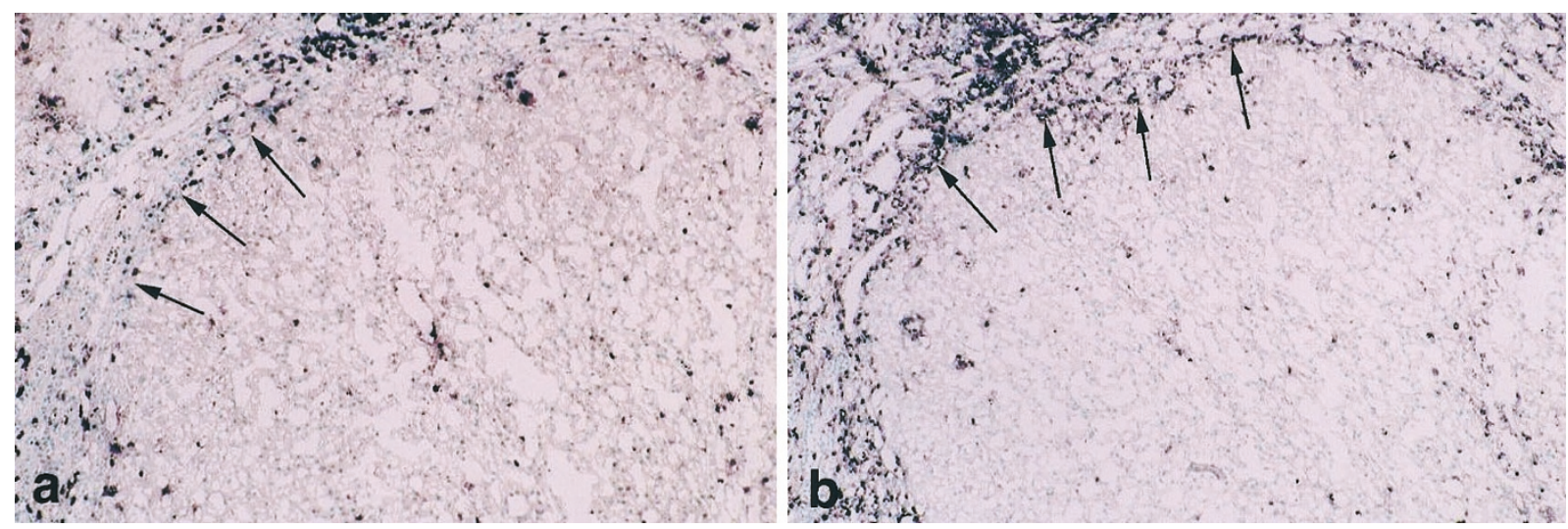

\section{Figure 3.}

Immunohistochemistry of CD45RA and CD45R0 in the liver cells of patients with chronic hepatitis C. CD45RA-positive (naive T cells) and CD45R0-positive cells (active T cells) in the portal area ( $a$ and $b$ ). CD45R0-positive cells $(b)$ are more predominant than CD45RA-positive cells ( $a$ ) at sites of piecemeal necrosis (arrows), suggesting the involvement of active $T$ cells $(a$ and $b)$. Slides counterstained with methyl green. Magnification: $\times 64$.

Table 1. Quantitative Data from 40 anti-HCV Antibody Seropositive Patients

\begin{tabular}{lc}
\hline & Mean SE \\
\hline beta-actin-mRNA & $728.5 \pm 183.7$ \\
DC-CK1-mRNA & $7.460 \pm 2.088$ \\
RANTES-mRNA & $7.948 \pm 2.185$ \\
DC-CK1-/beta-actin-mRNA & $0.019 \pm 0.005$ \\
RANTES-/beta-actin-mRNA & $0.016 \pm 0.003$ \\
\hline
\end{tabular}

as cirrhosis and alcoholic or autoimmune hepatitis, compared with those of normal controls (Sheron et al, 1993). In chronic hepatitis C, IL-8-mRNA expression is also associated with a significant histological activity index (HAl) (Shimoda et al, 1998). Levels of a CXC chemokine, GRO- $\alpha$, are elevated in the diseased liver, especially in viral hepatitis (Maltby et al, 1996). In contrast, levels of another CXC chemokine, referred to as "human intercrine reduced in hepatomas stromal cell-derived factor $1 /$ pre- $\beta$-cell growth-stimulating factor," which exhibits in vivo chemotactic activity to neutrophils, lymphocytes, and monocytes in a rat intradermal injection model, are not associated with the HAl in chronic hepatitis C (Shimoda et al, 1998).

Lymphocytes are involved in chronic hepatitis C (Freni et al, 1995; Mosnier et al, 1993; 1998; Scheuer et al, 1992). C-C chemokines attract lymphocytes and may therefore play an important role in chronic hepatitis C. RANTES levels are elevated in viral hepatitis (Maltby et al, 1996). We therefore investigated the involvement of DC-CK1 and RANTES in clinical samples of livers from patients with chronic hepatitis $\mathrm{C}$. DC-CK1 attracts naive $\mathrm{T}$ cells and is produced by dendritic cells in the portal area (Adema et al, 1997; Kudo et al, 1997; Prickett et al, 1988). Dendritic cells can present antigen to cytotoxic $\mathrm{T}$ lymphocytes (Adema et al, 1997; Hieshima et al, 1997). By contrast, RANTES accounts for the chemo-attractive properties of active $\mathrm{T}$ cells, according to results from an in vitro study (Schall et al, 1990). The results from our in situ hybridization and immunohistochemical study indi- cated that DC-CK1 was expressed in mononuclear cells in association with naive $\mathrm{T}$ cell infiltration in the portal area and that RANTES was expressed by the cells adjacent to active $T$ cells at sites of piecemeal necrosis. These results are essentially compatible with those of the in vitro study and suggest that the portal area is the initiation site of immune responses in chronic hepatitis $\mathrm{C}$. The elevated DC-CK1- and RANTES-mRNA levels were significantly associated with a category II (intralobular degeneration and focal necrosis) HAl score ( $p<0.05$, data not shown). This finding suggests that both chemokines are involved in immune responses to $\mathrm{HCV}$ infection because the degree of the category II HAI score may directly reflect the killing of HCV-infected hepatocytes in the lobules by cytotoxic T cells (Kojima et al, 1996; Tanaka et al, 1993). The significant correlation between the levels of the mRNA of these two chemokines and the serum ALT levels, which reflect hepatocyte death, also support this notion. The most striking histopathological features of chronic active hepatitis $\mathrm{C}$ are portal lymphoid follicles and periportal inflammation (Mosnier et al, 1993; Scheuer et al, 1992). The follicle comprises a core of B cells mixed with many T-helper/inducer lymphocytes. The outer ring is composed predominantly of T-suppresser/cytotoxic lymphocytes (Freni et al, 1995). This similarity of portal lymphoid follicles to lymph nodes where DC-CK1 mRNA was originally found (Adema et al, 1997) gives support to the idea that the results of the in vitro study can be extrapolated to HCV infection in the liver.

Our study does not provide direct evidence that C-C chemokines activate the portal immune response against chronic hepatitis $C$ in vivo. However, the in vitro results (Adema et al, 1997) exclude the likelihood that the expression of these chemokines is an epiphenomenon associated with portal inflammation. The findings of our study do suggest that DC-CK1 and RANTES play important roles in the immune response to HCV infection in and around the portal area by attracting naive and active $\mathrm{T}$ cells. 

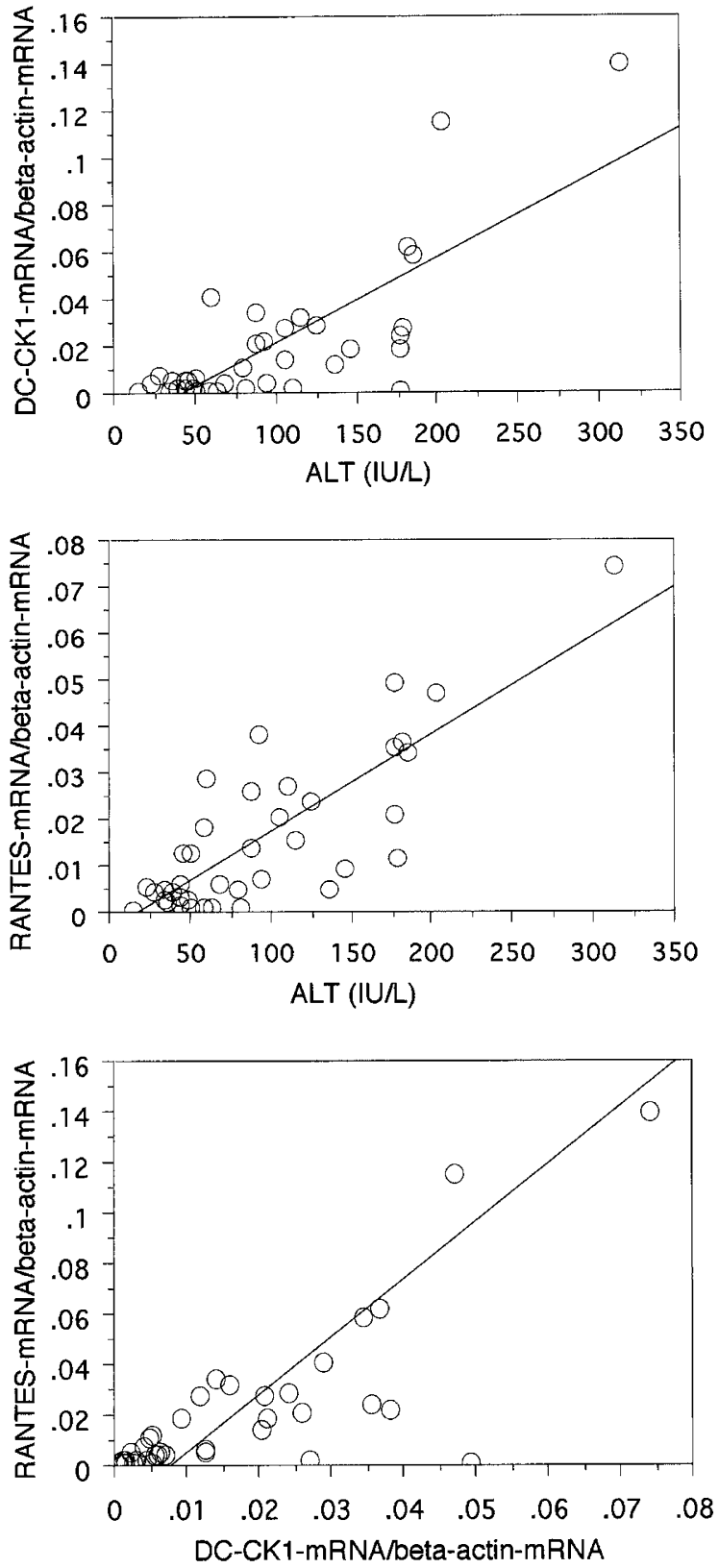

\section{Figure 4.}

Correlation between serum ALT levels and DC-CK1 mRNA or RANTES mRNA in the liver cells of patients with chronic hepatitis C. Both DC-CK1 mRNA and RANTES mRNA corrected by comparison with $\beta$-actin mRNA, are significantly correlated with serum ALT levels $(r=0.783$ and 0.813$)(a$ and $b)$. Correlation between DC-CK $1 / \beta$-actin mRNA and RANTES/ $\beta$-actin mRNA is also significant $(r=0.786)(c)$.

\section{Materials and Methods}

\section{Patients}

Forty patients (30 men and 10 women) with various stages of chronic hepatitis $C$ and six controls whose livers were anti-HCV-antibody negative (three with fatty liver, one with a cholangiocarcinoma adjacent to the normal liver, and two with gastric cancers and liver metastases adjacent to the normal liver) were enrolled in this study between 1994 and 1999. Inclusion criteria
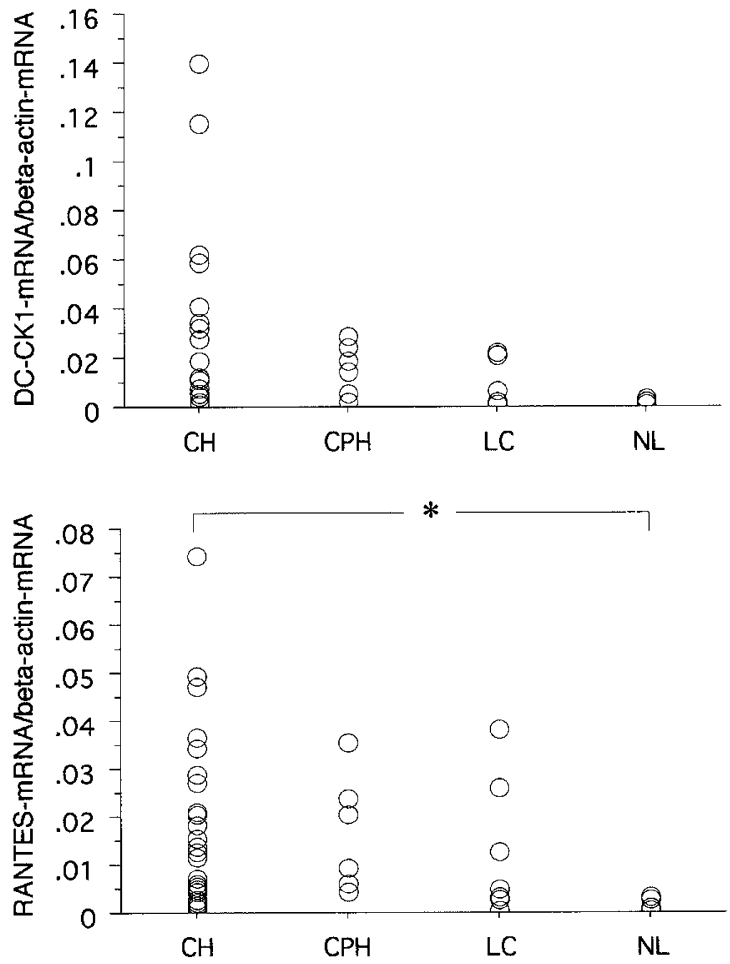

Figure 5.

DC-CK1-mRNA and RANTES-mRNA levels in the liver at various stages of chronic hepatitis $C$ and in controls. DC-CK $1 / \beta$-actin-mRNA levels do not significantly differ among groups (a), whereas RANTES/ $\beta$-actin-mRNA levels are significantly elevated in patients with chronic active hepatitis $C$ compared with those with normal livers ( ${ }^{*} p<0.05$, by Bonferroni/Dunn analysis) $(b)$. $\mathrm{CH}$, chronic active hepatitis; $\mathrm{CPH}$, chrome persistent hepatitis; LC, liver cirrhosis; NL, normal liver.

was the presence of anti-HCV antibodies as determined by a second-generation RIA kit (Dynabot, Abbott Park, Illinois), presence of serum HCV RNA detected by RT-PCR (Amplicore kit, Roche, Basel, Switzerland), and a liver biopsy with histological findings compatible with those of chronic hepatitis (with or without cirrhosis). Exclusion criteria were positive markers of hepatitis B virus infection, a history of daily alcohol consumption of more than $40 \mathrm{~g}$, serological evidence of autoimmune disease (antinuclear and/or antimitochondrial antibodies), and a history of medication at biopsy. Biochemical data were obtained at the time of biopsy. Clinical profiles of these patients are summarized in Table 2. Histological examination of anti-HCV-antibody-positive samples revealed a variable degree of activity and the fibrosis of chronic liver disease. In contrast, all anti-HCV antibody-negative samples showed activity ranging from none to minimal inflammation. Informed consent to participate in the study was obtained from all patients and approved by the ethics committee.

\section{Tissue Preparation}

Liver biopsy samples were obtained from patients with chronic hepatitis C. For immunohistochemical staining, a portion of each sample was mounted in orni- 
Table 2. Clinical and Biochemical Data from 40 anti-HCV Antibody Seropositive Patients (30 men, 10 women) with Controls

\begin{tabular}{lcccc}
\hline & Sex (M/F) & Age $(\mathrm{yr})$ & ALT $(\mathrm{IU} / \mathrm{L})$ & HAl score \\
\hline CPH & $5 / 1$ & $45.8 \pm 5.02$ & $105 \pm 22.6$ & $3.83 \pm 0.401$ \\
CAH & $21 / 6$ & $50.6 \pm 2.00$ & $103 \pm 13.3$ & $8.85 \pm 0.433$ \\
LC & $4 / 3$ & $63.2 \pm 2.11$ & $53.1 \pm 10.5$ & $10.0 \pm 1.66$ \\
Control & $3 / 3$ & $47.2 \pm 4.94$ & $41.2 \pm 8.91$ & \\
\hline
\end{tabular}

ALT, alanine transaminase; HAl score, Histology Activity Index score of Knodell et al.; CAH, chronic active hepatitis; CPH, chronic persistent hepatitis; LC, liver cirrhosis.

Values are expressed as mean $\pm \mathrm{SE}$

thine carbamoyltransferase, rapidly frozen in liquid nitrogen, and stored at $-80^{\circ} \mathrm{C}$. One portion was fixed in $10 \%$ buffered formalin, embedded in paraffin, stained with hematoxylin eosin and Masson's trichrome, and another was immediately fixed in $4 \%$ paraformaldehyde, then mounted in ornithine carbamoyltransferase for in situ hybridization. The remainder was rapidly homogenized with a glass rod in one $\mathrm{ml}$ of ISOGEN (Wako, Osaka, Japan) and stored at $-80^{\circ} \mathrm{C}$ until RNA extraction and RT-PCR assay.

\section{In Situ Hybridization of DC-CK1 and RANTES mRNA in the Liver}

We performed in situ hybridization using digoxigeninlabeled riboprobes to identify the cells involved in DC-CK1 and RANTES production in the liver. RNA probes were generated from cloned pGEM-T (Promega, Madison, Wisconsin) encoding DC-CK1 and RANTES cDNA. Antisense or sense probes were generated by transcription with T7 RNA polymerase in the presence of digoxigenin-labeled UTP (Boehringer Mannheim, Indianapolis, Indiana). Each RNA probe included 216 base (DC-CK1 nt: 509-724, numbers denoting positions of the nucleotide sequence according to GeneBank accession no. NM002988) and 200 base (RANTES nt:155-354, GeneBank accession no. M21121) fragments, respectively.

Frozen sections (5- $\mu \mathrm{m}$ thickness) fixed in $4 \%$ paraformaldehyde were digested with proteinase $\mathrm{K}$ (1 $\mathrm{mg} / \mathrm{ml}$ PBS) (BRL, Gaithersburg, Maryland) at $37^{\circ} \mathrm{C}$ for 5 minutes, then incubated in $10 \mu$ of hybridization buffer $(50 \%$ deionized formamide, $10 \%$ dextran sulfate, $1 \times$ Denhardt's solution, $0.3 \mathrm{M} \mathrm{NaCl}, 1 \mathrm{mM}$ sperm DNA (Boehringer Mannheim), $500 \mathrm{mg} / \mathrm{ml}$ yeast tRNA (Boehringer Mannheim), and $80 \mathrm{ng} / \mathrm{ml}$ digoxigeninlabeled cRNA probe at $50^{\circ} \mathrm{C}$ overnight. The sections were washed in $2 \times \mathrm{SSC} / 50 \%$ formamide for $30 \mathrm{~min}$ utes, then in $2 \times \mathrm{SSC}$ at $50^{\circ} \mathrm{C}$ for 10 minutes before digestion with DNase-free-RNase A $(500 \mathrm{mg} / \mathrm{ml})$ (Boehringer Mannheim) in $0.5 \mathrm{M} \mathrm{NaCl}, 10 \mathrm{mM}$ Tris $\mathrm{HCl}$ $(\mathrm{pH} 8.0)$ at $37^{\circ} \mathrm{C}$ for 30 minutes. The slides were immersed in maleate buffer $(\mathrm{pH} 7.5)$ containing $1 \%$ blocking reagent (Boehringer Mannheim) at room temperature for 30 minutes, then incubated in alkalinephosphatase conjugated anti-digoxigenin-Fab (Boehringer Mannheim) for 120 minutes. Color was visualized with nitroblue, 5-bromo-4-chloro-3-indolyl phosphate (BRL), and levamisole in $100 \mathrm{mM}$ Tris buffer ( $\mathrm{pH}$ 9.5), then the sections were counterstained with methyl green and mounted in 95\% glycerol/PBS.

\section{Immunohistochemical Analysis of T Cells in the Liver}

Serial sections were immunostained with CD45RA (a marker for naive $T$ cells) and CD45RO (a marker for active $T$ cells) to study T-cell activation. Briefly, 5 $\mu \mathrm{m}$-thick frozen sections were fixed in cold acetone, then incubated with mouse monoclonal anti-CD45RA (Sigma, St. Louis, Missouri) or anti-CD45RO (Sigma) antibodies. Positivity was detected using rabbit antimouse IgG antibodies conjugated with alkalinephosphatase. Each 30-minute incubation period was followed by a 15 -minute wash with Tris buffer. Color was visualized, and slides were counterstained as described above for in situ hybridization. Primary antibodies were replaced by mouse ascitic fluid in control samples.

\section{RNA Extraction and CDNA Synthesis}

Total RNA was extracted from liver biopsy specimens (approximately $3 \mathrm{mg}$ ) using acid guanidinium thiocyanate-phenol-chloroform (Chomczynski and Sacchi, 1987). Extracted RNA (1-5 $\mu \mathrm{g})$ and random hexamers (160 pmol; Takara, Japan) were denatured at $70^{\circ} \mathrm{C}$ for 10 minutes, cooled, and mixed with $50 \mathrm{~mm}$ Tris- $\mathrm{HCl}, \mathrm{pH} 8.3,75 \mathrm{mM} \mathrm{KCl}, 3 \mathrm{mM} \mathrm{MgCl} 2,10 \mathrm{~mm}$ DTT, $0.5 \mathrm{~mm}$ dNTP, and 200 units of MuLV reverse transcriptase (BRL).

\section{PCR Amplification and Quantification}

Rapid thermal cycling and continuous monitoring of PCR products proceeded using a LightCycler (Idaho Technology, Idaho Falls, Idaho). One microliter of the cDNA mix was used as a template for the amplification reaction. Before adding the primers and CDNA, $0.16 \mu \mathrm{l}$ TaqStart antibody (Clontech, Palo Alto, California) was added to $2 \mu \mathrm{l}$ LightCycler-DNA Master SYBR Green I (10 $\times$ concentration) (Boehringer Mannheim) and incubated at room temperature for 5 minutes. The mixture contained $3 \mathrm{mM} \mathrm{MgCl}_{2}$ and $0.3 \mu \mathrm{M}$ of upstream and downstream primers. The sequences of the primers are shown in Table 3. Amplification and thermal cycling proceeded as follows: initial denaturation at $95^{\circ} \mathrm{C}$ for 2 minutes, followed by 50 cycles of denaturation at $95^{\circ} \mathrm{C}$ for 0 seconds, annealing at $55^{\circ} \mathrm{C}$ for 5 seconds, and extension at $72^{\circ} \mathrm{C}$ for 20 seconds. 


\begin{tabular}{lccc}
\hline & Sequence & nt position* & Expected product size \\
\hline beta-actin forward & 5'-AGAAAATCTGGCACCACACC-3' & $289-308$ & $434 \mathrm{bp}$ \\
beta-actin reverse & 5'-CCATCTCTTGCTCGAAGTCC-3' & $704-723$ & $436 \mathrm{bp}$ \\
DC-CK1 forward & 5'-GCCAGGTGTCATCCTCCTAA-3' & $229-248$ & $315 \mathrm{bp}$ \\
DC-CK1 reverse & 5'-GGCACAATGTCTGCTGAGAA-3' & $645-664$ & $40-59$ \\
RANTES forward & 5'-CGGCACGCCTCGCTGTCATC-3' & $335-354$ & \\
RANTES reverse & 5'-GCAAGCAGAAACAGGCAAAT-3' & \\
\hline
\end{tabular}

* Nucleotide position according to GeneBank, accession numbers as follows; beta-actin, M10277; DC-CK1, NM002988; RANTES, M21121.

Fluorescence signals were acquired from each sample at the end of every extension step for $50 \mathrm{msec}$. To distinguish specific from nonspecific products, a melting curve was obtained immediately after amplification by holding the temperature at $65^{\circ} \mathrm{C}$ for 10 seconds followed by a gradual increase to $95^{\circ} \mathrm{C}$ at a rate of $0.2^{\circ} \mathrm{C}$ per second. To verify the melting curve results, the $\mathrm{PCR}$ reactions were resolved on $1.6 \%$-agarose gels in TBE buffer.

We confirmed that the amplified PCR products of $\beta$-actin, DC-CK1, and RANTES cDNA were identical to the reported sequences (GeneBank accession number of $\beta$-actin: M10277). The products were then purified with Microcon-100 (Millipore, Bedford, Massachusetts) and used as standards. The yields were optically determined and diluted at $10^{2}, 10^{3}, 10^{4}, 10^{5}$, $10^{6}, 10^{7}$, and $10^{8}$ copies. The diluted PCR products were amplified as standards for each run.

\section{Histopathological Evaluation}

Biopsy specimens were histologically assessed by independent pathologists according to the histological activity index (HAl) as described by Knodell et al (1981) and proposed by Desmet et al (1994) and Ludwig (1993).

\section{Statistical Analysis}

Statistical analysis was performed using Statview 4.0 software (Abacus Concepts, Inc., Berkeley, California). Partial associations were determined using the hierarchical log-linear analysis in a multiway cross tabulation. Groups were compared by the Bonferroni/Dunn analysis with a multiple comparison test; $p<0.05$ was considered statistically significant.

\section{References}

Adema GJ, Hartgers F, Verstraten R, Vries E, Marland G, Menon S, Foster J, Xu Y, Nooyen P, McClanahan T, Bacon KB, and Figdor CG (1997). A dendritic-cell-derived C-C chemokine that preferentially attracts naive $T$ cells. Nature 387:713-717.

Austyn JM (1998). Dendritic cells. Curr Opin Hematol 5:3-15.

Bacon KB and Schall TJ (1996). Chemokines as mediators of allergic inflammation. Int Arch Allergy Immunol 109:97-109.

Baggiolini M, Dewald B, and Moser B (1994). Interleukin-8 and related chemotactic cytokines-CXC and CC chemokines. Adv Immunol 55:97-179.
Chomczynski P and Sacchi N (1987). Single-step method of RNA isolation by acid guanidinium thiocyanate-phenolchloroform extraction. Anal Biochem 162:156-159.

Desmet VJ, Gerber M, Hoofnagle JH, Manns M, and Scheuer PJ (1994). Classification of chronic hepatitis: Diagnosis, grading and staging. Hepatology 19:1513-1520.

Dienes HP, Popper H, Arnold W, and Lobeck H (1982). Histologic observations in human hepatitis non-A, non-B. Hepatology 2:562-571.

Freni MA, Artuso D, Gerken G, Spanti C, Marafioti T, Alessi N, Spadaro A, Ajello A, and Ferrau O (1995). Focal lymphocytic aggregates in chronic hepatitis C: Occurrence, immunohistochemical characterization, and regulation to markers of autoimmunity. Hepatology 22:389-394.

Hedrick JA and Zlotnik A (1996). Chemokines and lymphocyte biology. Curr Opin Immunol 8:343-347.

Hieshima K, Imai T, Baba M, Shoudai K, Ishizuka K, Nakagawa T, Tsuruta J, Takeya M, Sakaki Y, Takatsuki K, Miura R, Opdenakker G, Van Damme J, Yoshie O, and Nomiyama H (1997). A novel human C-C chemokine PARC that is most homologous to macrophage-inflammatory protein-1-alpha/ LD78-alpha and chemotactic for T lymphocytes, but not for monocytes. J Immunol 159:1140-1149.

Knodell RG, Ishak KG, Black WC, Chen TS, Craig R, Kaplowitz N, Kiernan TW, and Wollman J (1981). Formulation and application of a numerical scoring system for assessing histological activity in asymptomatic chronic active hepatitis. Hepatology 1:431-435.

Kojima S, Tanaka Y, Enomoto N, Marumo F, and Sato C (1996). Distribution of hepatitis $C$ virus RNA in the liver and its relation to histopathological changes. Liver 16:55-60.

Kudo S, Matsuno K, Ezaki T, and Ogawa M (1997). A novel migration pathway for rat dendritic cells from the blood: hepatic sinusoids-lymph translocation. J Exp Med 185:777784.

Ludwig J (1993). The nomenclature of chronic active hepatitis: an obituary. Gastroenterology 105:274-278.

Maltby J, Wright S, Bird G, and Sheron N (1996). Chemokine levels in human liver homogenates: Associations between GRO alpha and histopathological evidence of alcoholic hepatitis. Hepatology 24:1156-1160.

Miller MD and Krangel MS (1992). Biology and biochemistry of the chemokines: A family of chemotactic and inflammatory cytokines. Crit Rev Immunol 12:17-46.

Mosnier JF, Degott C, Marcellin P, Henin D, Erlinger S, and Benhamou JP (1993). The intraportal lymphoid nodule and its environment in chronic active hepatitis C: An immunohistochemical study. Hepatology 17:366-371. 
Mosnier JF, Pham BN, Scoazec JY, Dubois S, Marcellin P, Martinot-Peignoux M, Degos F, Erlinger S, and Degott $C$ (1998). Relationship between the effector T-cell response and viremia in symptomatic chronic hepatitis C. Arch Pathol Lab Med 122:416-422.

Oppenheim JJ, Zachariae COC, Mukaida N, and Matsushita K (1991). Properties of novel proinflammatory supergene intercrine cytokine family. Annu Rev Immunol 9:617-648.

Oppenheim JJ (1993). Overview of chemokines. Adv Exp Med Biol 351:183-186.

Prickett TC, McKenzie JL, and Hart DN (1988). Characterization of interstitial dendritic cells in human liver. Transplantation 46:754-761.

Schall TJ, Bacon K, Toy KJ, and Goeddel DV (1990). Selective attraction of monocytes and $T$ lymphocytes of the memory phenotype by cytokine RANTES. Nature 347:669671.

Scheuer PJ, Ashrafzadeh P, Sherlock S, Brown D, and Dusheiko GM (1992). The pathology of hepatitis C. Hepatology 15:567-571.

Sheron N, Bird G, Koskinas J, Portmann B, Ceska M, Lindley I, and Williams R (1993). Circulating and tissue levels of the neutrophil chemotaxin interleukin-8 are elevated in severe acute alcoholic hepatitis, and tissue levels correlate with neutrophil infiltration. Hepatology 18:41-46.
Shimoda K, Begum NA, Shibuta K, Mori M, Bonkovsky HL, Banner BF, and Barnard GF (1998). Interleukin-8 and hIRH (SDF1-alpha/PBSF) mRNA expression and histological activity index in patients with chronic hepatitis C. Hepatology 28:108-115.

Sprecher E and Becker Y (1993). Role of Langerhans cells and other dendritic cells in viral diseases. Arch Virol 132:128.

Steinman RM (1991). The dendritic cell system and its role in immunogenicity. Annu Rev Immunol 9:271-296.

Steinman RM, Witmer-Pack M, and Inaba K (1993). Dendritic cells: antigen presentation, accessory function and clinical relevance. Adv Exp Med Biol 329:1-9.

Tanaka Y, Enomoto N, Kojima S, Tang L, Goto M, Marumo F, and Sato C (1993). Detection of hepatitis C virus RNA in the liver by in situ hybridization. Liver 13:203-208. 